\title{
Advanced ultrasound techniques in small animal reproduction imaging
}

\author{
George Mantziaras $^{1}$ (D) | Gaia Cecilia Luvoni ${ }^{2}$
}

${ }^{1}$ EchoVet Small Animal Clinic, Marousi, Athens, Greece

${ }^{2}$ Dipartimento di Scienze Veterinarie per la Salute, la Produzione Animale e la Sicurezza Alimentare, Università degli Studi di Milano, Milano, Italy

Correspondence

George Mantziaras, EchoVet Small Animal Clinic, Kifissias Avenue 22, Marousi, Athens 15125, Greece.

Email: gmantziaras@yahoo.com

\begin{abstract}
Ultrasonography is the imaging technology of choice for the evaluation of the reproduction system and of pregnancy in both humans and animals. Over the past 10 years, there have been significant technological improvements of the equipment, while new technologies have been developed. Doppler, contrast-enhanced ultrasonography, elastography, and 3D/4D ultrasonography are advanced ultrasound techniques that have been designed as methods to increase the diagnostic sensitivity of twodimensional (b-mode) ultrasound, and not as stand-alone tests. The basic physics as well as the advantages and limitations of these advanced ultrasound methods are briefly described. In the reproductive diagnostics of small animals, these techniques have gained an increased popularity as proved by the increased publication of several reports that are also briefly summarized in this review. Clinical applicability is to date limited because of a lack of research on the diagnostic value in concrete situations. Future research projects should focus also on standardization of the used techniques, on determination of thresholds to discriminate between healthy or diseases or fertile versus infertile and on the predictive value of advanced ultrasound findings. Continuing development and optimization of different ultrasound techniques as well as the increase of related scientific interest and worldwide research promises that the clinical interest on the use of advanced ultrasound techniques will increase in future.
\end{abstract}

KEYWORDS

3D/4D, CEUS, contrast-enhanced ultrasonography, Doppler, elastography, ultrasound

\section{1 | INTRODUCTION}

Ultrasonography is the imaging technology of choice for the evaluation of the reproduction system and pregnancy in both humans and animals. Today, ultrasound equipments are smaller, cheaper, and much more efficient. These upgrades, along with image digitization, have pushed ultrasound into the point-of-care setting. The most recent advances of different ultrasound techniques and their potential use in reproduction imaging of small animals are described in this review.

\section{2 | DOPPLER}


In small animal reproduction, Doppler ultrasonography has gained an increased popularity. Doppler study of canine maternal and foetal vessels and their changes during pregnancy has been described by Nautrup, 1998 and by Di Salvo, Bocci, Zelli, \& Polisca, 2006. Doppler in canine pregnancy was first reviewed by Blanco, Arias, \& Gobello, 2008. The cardiovascular system of the bitch and foetal blood flow during normal and abnormal pregnancy were also evaluated by Blanco and co-workers (Blanco et al., 2009; Blanco, Batista, Gómez, Arias, \& Gobello, 2012; Blanco, Rodríguez, et al., 2011; Blanco, Tórtora, Rodríguez, Arias, \& Gobello, 2011). Doppler characteristics of the middle cerebral artery in canine foetuses were published in 2013 (Feliciano et al., 2013). Recently, the reference range of gestational uterine artery resistance index in small canine breeds was published (Batista et al., 2018).

In the cat, the development of uteroplacental and foetal feline circulation with Doppler was recorded by Pereira et al. (2012). Doppler parameters of uterine, umbilical, and foetal vessels during normal gestation were studied in 2014 (Blanco et al., 2014), and more recently, it has been shown that blood flow of the uterine and umbilical arteries differed between normal and abnormal gestations predicting an adverse obstetric outcome. These differences appeared earlier, before clinical symptoms or other abnormal ultrasonographic findings (Blanco et al., 2016). Doppler studies of the utero-placental arterial vessels in pregnant rabbits as well as changes of the umbilical cord, aorta, and caudal vena cava of foetuses have also been described (Polisca, Scotti, Orlandi, Brecchia, \& Boiti, 2009).

In canine and feline pregnancy, heart rate has been considered an excellent indicator to monitor foetal hypoxia and complications related to growth restriction due to placental insufficiency, from 23 to 25 days after the LH surge until parturition (Gil, Garcia, Giannico, \& Froes, 2014; Yeager \& Concannon, 1990; Zone \& Wanke, 2001). Normal foetal heart rate has been reported to be $180-220 \mathrm{bpm}$ (Peterson \& Kutzler, 2011), whereas maternal heart rate ranges between 70 and 120 bpm (Lucio, Silva, Rodrigues, Veiga, \& Vannucchi, 2009). Spectral Doppler is a very accurate method to estimate foetal heart rate and is widely used in clinical practice (Vestegen, Silvia, Onclin, \& Donnay, 1993; Zone \& Wanke, 2001). Maternal heart rate, foetal heart rate and their ratio were monitored with Doppler in uncomplicated pregnancies as parameters for the evaluation of foetal well-being (Alonge, Mauri, Faustini, \& Luvoni, 2016). Evaluation of Doppler parameters of the umbilical artery and the uterine artery has been also used to assess foetal viability and late gestational foetal distress (Giannico, Gil, Garcia, \& Froes, 2015; Miranda \& Domingues, 2010) and to predict delivery time in the bitch. Resistance index of the umbilical artery declined before parturition, while in cases of foetal distress, this decrease was followed by an increase beginning 12 hr before c-section (Giannico, Garcia, Gil, Sousa, \& Froes, 2016; Giannico et al., 2015). Doppler allowed early detection of hemodynamic changes in conceptuses with abnormalities, as changes in the flow of uteroplacental and umbilical arteries were observed before B-mode findings (Freitas, Mota, Silva, Carvalho, \& Silva, 2016).

During normal canine puerperium, uterine artery RI progressively increased, in association with the two-dimensional (2D) ultrasonographic regression of the uterus (Batista et al., 2013). In the cat, two-dimensional and pulsed wave Doppler ultrasonographic changes of uterine involution during normal feline puerperium have also been described. Uterine artery blood flow progressively decreased during the first 25 days after parturition, in accordance with its B-mode regression (Blanco et al., 2015).

Uterine artery RI and PI were significantly lower in normal delivery than in c-section bitches during uterine involution (Barbosa et al., 2013). Interestingly, reduced fertility of bitches was linked to impaired diastolic flow of the uterine artery (Freeman, Russo, \& England, 2013).

In bitches with pyometra, endometrial hyperplasia, with or without luminal content, the uterine artery blood flow velocity was higher than in normal ones (Batista et al., 2016). Uteri of bitches with cystic endometrial hyperplasia-pyometra syndrome showed inflammatory process characterized by COX-2 expression, resulting in not only inflammatory and proliferative, but also vascular disorders, demonstrated by increased blood flow and lower vascular resistance (Veiga et al., 2017). In 2018, Doppler was also used to evaluate pyometra in cats. Queens with pyometra had higher RI when compared to queens at early pregnancy (Blanco et al., 2018).

In normal bitches, a significant increase in uterine artery blood velocity and a decrease in the RI after mating have been reported, while in bitches with endometrial hyperplasia, RI was higher, indicating that endometrial hyperplasia results in a lower uterine perfusion, and a blunted vasodilation response to mating (England, Moxon, \& Freeman, 2012).

Intraovarian colour flow perfusion increased gradually during pro-oestrus (Figures 1 and 2). In the pre-ovulatory period intraovarian colouring and blood flow velocities were increased, while $\mathrm{PI}$ and RI were declined. Maximum perfusion was observed at ovulation and during the early luteal phase. Significant differences were detected in all calculated Doppler parameters 2 days before and 2 days after ovulation and intraovarian blood flow decreased gradually in accordance with luteal regression (Köster, Poulsen, \& Günzel-Apel, 2001). Similar results were published by Jurczak and Janowski (2018), who concluded that arterial blood flow of the ovary, when measured around ovulation, does not allow precise detection of exact ovulation time in bitches, as it remains higher for a period of 4 days. Colour Doppler ultrasound performed once daily was more accurate in identifying the pre-ovulatory LH peak than B-mode ultrasound and enabled prospective determination of ovulation (Bergeron, Nykamp, Brisson, Madan, \& Gartley, 2013).

Ovarian blood flow parameters during the luteal phase of pregnant bitches were comparable to those of non-pregnant bitches (Köster et al., 2001). Administration of aglepristone in dogs during the mid-luteal phase accelerated luteolysis which is accompanied by a parallel decline in ovarian blood flow (Polisca et al., 2010). Significant differences of ovarian blood supply and progesterone between pregnant and non-pregnant bitches have been reported. Blood flow pattern during dioestrus in pregnant bitches was not always closely related with progesterone production (Polisca, Zelli, et al., 2013). 


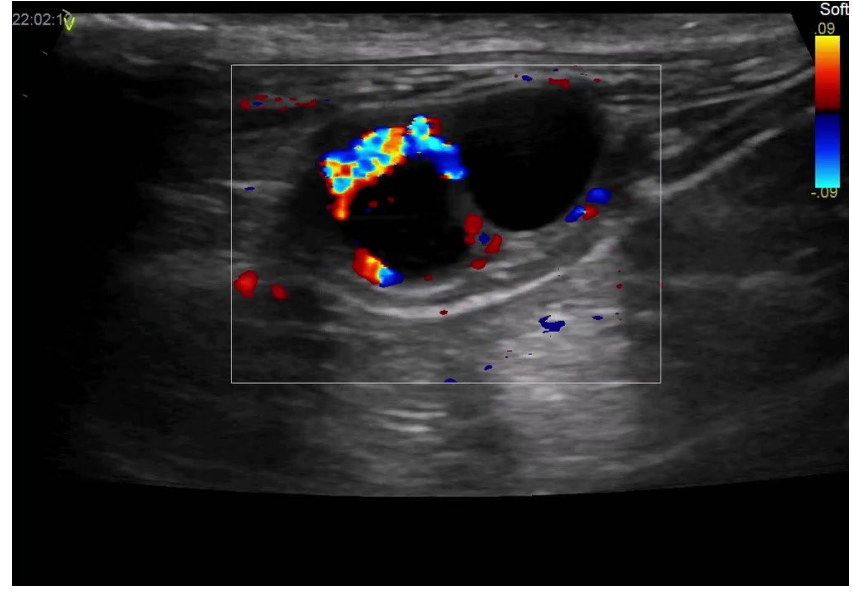

FIGURE 1 Color Doppler study of a canine ovary at late proestrus

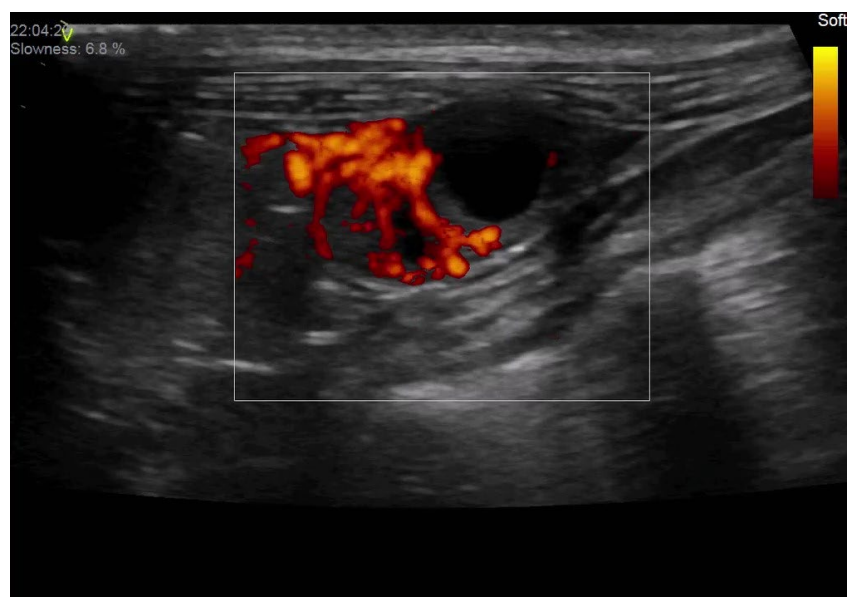

FIGURE 2 Power Doppler study of a canine ovary at late proestrus

The Doppler characteristics of the uterine artery in the anoestrus bitch were firstly described in a study of 2005 (Alvarez-Clau \& Liste, 2005). Their changes along the oestrus cycles were reported by Nogueira et al., 2017. The breed, the phase of oestrus cycle and also the pregnancy history affected Doppler parameters of the uterine artery, while RI did not differ during the different phases of the cycle for the same breed (Freitas, Mota, Silva, \& Silva, 2017). In cats, ovarian blood flow seemed to increase during sexual development until puberty (Vercellini et al., 2018).

The differentiation of benign from malignant mammary tumours is always challenging.

According to one study, the presence of vascularization or the characteristics of the colour Doppler pattern were not correlated with malignancy. The use of pulsed wave Doppler detected significantly higher maximum velocities in malignant tumours compared to benign ones (Feliciano, Vicente, \& Silva, 2012). In contrast, another study demonstrated that in benign tumours, the most common colour Doppler flow vascular pattern was the peripheral, while in cases of malignancy, the mixed pattern was the most frequent. Concerning vascular RI and PI, no significant differences were observed between benign and malignant tumours (Soler et al., 2016). Doppler was also used as a successful tool to assess the prognosis of treatment of acute canine mastitis (Trasch, Wehrend, \& Bostedt, 2007).

In male dogs, prostatic artery, capsular artery, parenchymal artery and recently trabecularis artery have been identified with Doppler examination of the prostate (Alonge, Melandri, Leoci, Lacalandra, \& Aiudi, 2018; Newell et al., 1998). No differences were identified in any Doppler parameters in dogs with prostatitis (Newell et al., 1998). Colour and pulsed wave (PW) Doppler, physiological and pathological characteristics of the canine testis, epididymis and prostate gland were described by Günzel-Apel, Möhrke, \& Poulsen Nautrup, 2001. Results showed that RI and PI increase in accordance with age. De Freitas, Pinto, Silva, and Silva (2015) also concluded that age influences Doppler sonographic parameters of the prostate, as Doppler signal and the diameter of the vessels were increased with increasing age. This change could be the result of hormonal influences related to age, as testosterone and oestrogen can promote androgenic receptor tissue growth and stimulate angiogenesis and vascular growth (Franck-Lissbrant, Haggstrom, Damber, \& Bergh, 1998). Prostatic vascular system could be a primary target of androgen action (Buttyan, Ghafar, \& Shabsigh, 2000). In dogs with benign prostatic hyperplasia (BPH), peak systolic velocity (PSV), end diastolic velocity (EDV) and pixel number were significantly higher than in normal ones (Zelli, Orlandi, Troisi, Cardinali, \& Polisca, 2013). Implantation of GnRH agonists decreased PSV, EDV and power Doppler pixel intensity in prostatic and subcapsular arteries, closely related to the decrease in serum testosterone concentration. The regression of the prostatic parenchyma in treated dogs occurred secondarily to the regression of the prostatic vascular system as a result of cell death mediated by tissue ischaemia/hypoxia (Polisca, Orlandi, et al., 2013). A recent study also concluded that treatment of dogs with $\mathrm{BPH}$ with finasteride reduces simultaneously the volume, and also local vascularization and blood flow of the prostate, suggesting that the course of therapy can be followed by analysing changes of the indices of the prostatic artery (Angrimani et al., 2018). These studies show that Doppler examination of prostatic blood flow can be an additional tool to follow up medical treatment of BPH.

Interestingly, the location of the prostatic artery measurements may influence Doppler parameters (Figure 3). Doppler indices were significantly reduced in the subcapsular and parenchymal branches compared to the cranial and caudal ones (de Freitas et al., 2015).

Doppler examination of the canine testis also showed that Doppler parameters are also location-depended (Carrillo, Soler, Lucas, \& Agut, 2012; de Souza et al., 2014; Gumbsch, Gabler, \& Holzmann, 2002; Trautwein, Souza, \& Martins, 2019). Not only regional, but important pubertal differences in the blood flow of testicular artery do exist (de Souza, Barbosa, et al., 2015).

It has been shown that RI and PI could be potential markers of seminal quality in dogs, as a negative correlation existed with total and progressive motility, and with the percentage of membrane intact sperms (Zelli, Troisi, Elad Ngonput, Cardinali, \& Polisca, 2013). Infertile dogs showed lower PSV and EDV measured in the distal 


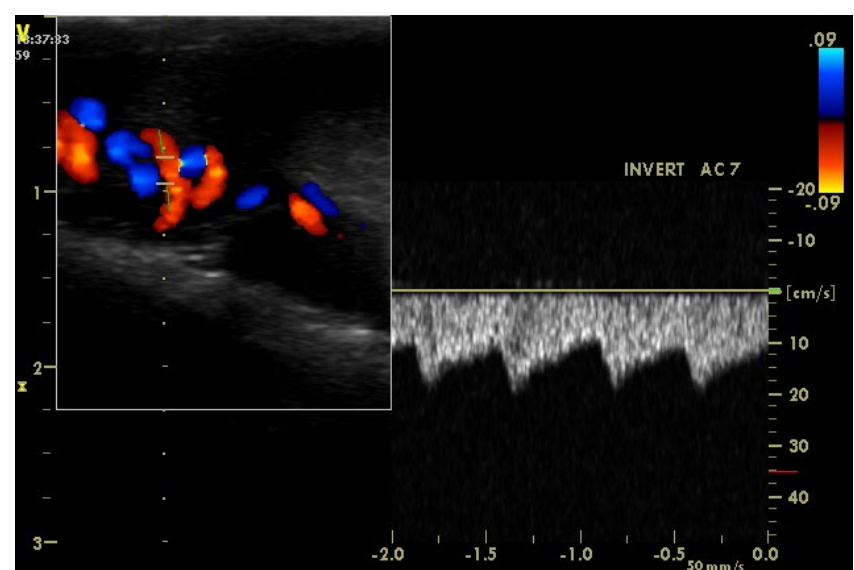

FIGURE 3 Pulsed Wave Doppler study of the canine pampiniform plexus

supratesticular artery, marginal testicular artery, and intratesticular artery when compared to fertile ones. Notably, RI and PI did not differ between infertile and fertile dogs (de Souza, England, et al., 2015). Testicular artery RI and PI were not predictive of future total sperm output or proportions of live normal sperm in dogs (England et al., 2017). Sexual rest should take place before the examination of the prostate with power or PW Doppler as Doppler parameters could be influenced by ejaculation (Alonge, Melandri, Fanciullo, Lacalandra, \& Aiudi, 2018a, 2018c; Alonge, Melandri, Leoci, et al., 2018).

Doppler ultrasound was used to differentiate benign from malignant lesions of the canine testes. In neoplasmatic lesions Doppler vascular signals were significantly increased around and inside the masses when compared with those measured in inflammatory and degenerative lesions (Bigliardi et al., 2019).

\section{3 | CONTRAST-ENHANCED ULTRASONOGRAPHY}

Contrast-enhanced ultrasonography (CEUS) is a novel technique that uses microbubble contrast agents injected intravenously or instilled into body cavities. Current ultrasound contrast agents (UCA) consist of small sized (1-10 mm diameter) microbubbles of an inert, relatively insoluble gas, encapsulated by a protein, lipid, or polymer shell, disrupted at higher incident pressures (Appis, Tracy, \& Feinstein, 2015; Calliada, Campani, Bottinelli, Bozzini, \& Sommaruga, 1998; Cosgrove \& Harvey, 2009; Figures 4 and 5).

Prostatic perfusion in the dog using CEUS was firstly described in 2001 and in 2009, with the use of different UCA (Hagen et al., 2001; Russo et al., 2009). Vascularity of the prostate in healthy dogs before and after the injection of UCA was also reported (Bigliardi \& Ferrari, 2011) when CEUS vascular perfusion kinetics was assessed in dogs with prostatic disease (Vignoli et al., 2011). According to this study, CEUS appears to show differences in perfusion that may help to discriminate malignant from benign lesions. The contrast enhanced sonographic characteristics of prostate gland disorders

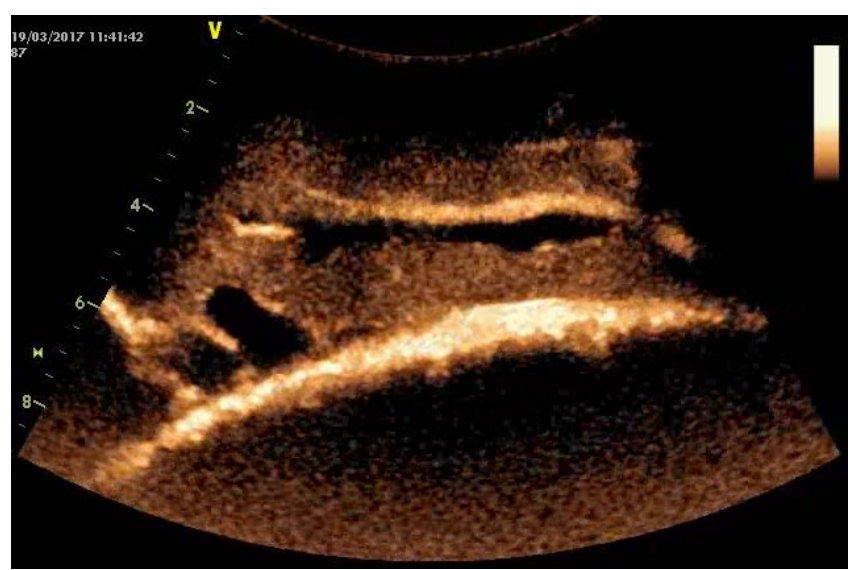

FIGURE 4 Arterial phase of contrast enhanced ultrasound study of a mammary gland in a ewe

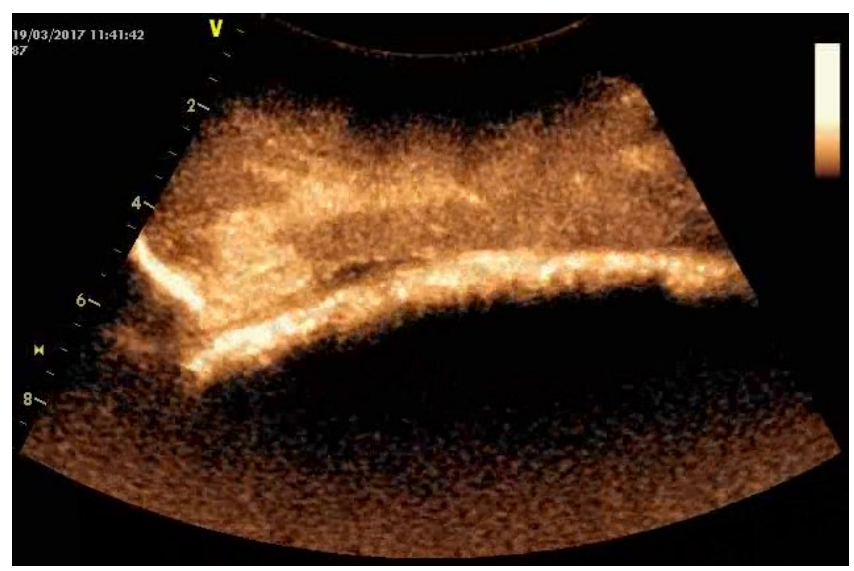

FIGURE 5 Wash-out phase of contrast enhanced ultrasound study of a mammary gland in a ewe

were also described (Russo, Vignoli, \& England, 2012; Troisi et al., 2015). In another study, CEUS examination of testes was performed and the conclusion was that inhomogeneous testes with a hyperenhancing pattern were associated with neoplasia, while testes with non-neoplastic lesions were characterized by a scant/moderate homogeneous enhancement. Perfusion parameters were also higher in neoplastic lesions. (Volta et al., 2014).

Contrast-enhanced and Doppler ultrasonography of the testicles in healthy adult cats has also been performed (de Brito et al., 2015). Perfusion patterns of the mammary gland and inguinal lymph node in intact bitches during the different stages of the estrous cycle have been described (Vanderperren et al., 2018). Maternal and foetal vessels of pregnant bitches were studied with UCA in the first twothirds of gestation, without any clinically relevant adverse effects (Orlandi et al., 2019).

\section{ELASTOGRAPHY}

Ultrasound elastography is a new technology measuring the elasticity and stiffness of tissues and increasing the diagnostic 
sensitivity of two-dimensional (b-mode) ultrasound (Ophir, Céspedes, Ponnekanti, Yazdi, \& Li, 1991). Depending on the force applied to the organ or tissue, several types of elastography techniques have been developed such as strain or real-time elastography, acoustic radiation force impulse imaging (ARFI), transient elastography, point shear wave elastography and shear wave elastography (Bamber et al., 2013; Figure 6).

Very few reports have been published in the literature concerning the use of elastography in small animal reproduction. Recently, a method to differentiate benign (softer) from malignant lesions (harder) using shear wave elastography in mammary tumours of 12 dogs was described (Glińska-Suchocka et al., 2013). Some other studies of ARFI and shear wave elastography in dogs with mammary tumours have shown that elastographic values for malignant tumours were significantly higher compared to benign tissues, indicating that this may be a useful technique for determining benign from malignant mammary lesions (Feliciano et al., 2014, 2018, 2017; Glińska-Suchocka et al., 2013). Canine foetal lungs and liver were studied with ARFI elastography during the final 5 days of intrauterine development (Rodrigues Simões et al., 2018).

The first report describing the normal elasticity findings of the normal canine prostate was conducted in 1999, as an in vitro study (Kallel, Price, Konofagou, \& Ophir, 1999). Parameters of ARFI elastography in dogs with normal prostate and testicles have been published (Feliciano et al., 2015). Normal values of strain elastography of the canine prostate were described in 2015 (Jeon et al., 2015) and of the normal testicles in 2016 (Mantziaras \& Luvoni, 2016). Elastography was also used as a diagnostic tool in a case of prostatic adenocarcinoma (Domosławska, Zduńczyk, Jurczak, \& Janowski, 2018).

A total of 300 cases of masses of mammary glands were evaluated with B-mode, Doppler, CEUS and ARFI elastography. CEUS proved to be ineffective in the differentiation of mammary tumours, but useful in the identification of macro and microcapillarization. On the other hand, ARFI elastography allowed malignancy prediction of canine mammary masses (Feliciano et al., 2017). It was also reported that B-mode ultrasonography, CEUS and ARFI elastography enabled the identification of some of the characteristics of high-grade mammary carcinoma types in female dogs with limited accuracy (Feliciano et al., 2018).

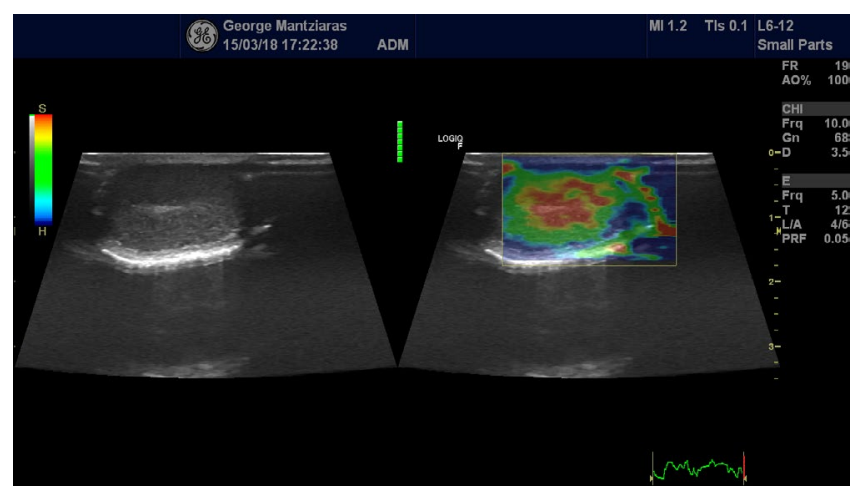

FIGURE 6 Strain elastography of the canine testicle

\section{5 | THREE-DIMENSIONAL (3D) AND FOUR-DIMENSIONAL (4D) ULTRASONOGRAPHY}

A three-dimensional (3D) ultrasound examination produces a series of still volumes that can be displayed in any plane after the examination, so they can be reconstructed as 3D images. 4D refers to a moving, real-time 3D imaging, where time is the fourth dimension (Hildebrandt et al., 2009). Good 3D images can be obtained from anatomical structures and pathologic conditions with a liquid content or from those adjacent to them (Cesarani, Isolato, Capello, \& Bianchi, 1999).

The use of 3D and 4D ultrasonography as monitoring tools of canine and feline pregnancy and of African lioness has been described (Hildebrandt et al., 2009, 2012).

In other species, as the horse and the elephant, the use of 3D and 4D ultrasound has been adopted for the imaging of the foetus (Drews et al., 2008; Kotoyori et al., 2012). In small animals, there are no reports or studies on the possible use of 3D or 4D ultrasound in the imaging of the normal ovarian changes during the oestrus cycle or describing ovarian pathological findings. Conversely, in large animals' reproduction, Scully, Evans, Duffy, and Crowe (2014) characterized dominant follicle (DF) and corpus luteum (CL) development through the oestrous cycle of cattle using 3D ultrasonography and compared it with 2D ultrasound. Conventional ultrasound measurements had higher repeatability, while 3D power Doppler measures of blood flow were more representative of vascular changes in the DF and $C L$ throughout the oestrous cycle. In the goat the use of $2 \mathrm{D}$ was compared with $3 \mathrm{D}$ ultrasound in the pregnant uterus and antenatal development of the foetus. It was concluded that 2D was better in visualizing fluids, while $3 \mathrm{D}$ images were better to view details of placentation of foetus with endometrium (Kumar, Chandolia, Kumar, Pal, \& Sandeep, 2015).

\section{6 | CONCLUSION}

Over the last years, several advanced ultrasound technologies have been developed which are dynamic methods, which may provide additional information of the examined organs or lesions, increasing the diagnostic sensitivity of two-dimensional ultrasound. All these innovative ultrasound technologies were developed to aid the diagnosis and differentiation of tissues abnormalities and not as stand-alone tests. Nevertheless, their clinical application in the field of small animal reproduction is still limited, and their use is affected by several variables. Many of the related studies published in the literature seem to have different or even controversial results. Colour and power Doppler lack of objectivity and quantification while they require immobilization of the animal as they detect motion; therefore, they are strongly influenced by movements of the animal or even by panting. Pulsed wave Doppler measurements are also influenced by motion, while the ultrasound beam should be as parallel as possible to the blood-flow direction in order to obtain accurate and repeatable measurements. The use of different anaesthetic or sedative protocols affects imaging with Doppler and CEUS, as they have different hemodynamic effect. Other 
research groups use strain elastography, others shear wave and others ARFI elastography. Concerning CEUS, different ultrasound contrast agents are used, and their indications depend on the approval patterns of individual countries' regulatory agencies.

Clinical applicability is to date limited also because of a lack of research on the diagnostic value in concrete situations. Sensitivity and specificity for the detection of specific conditions or diseases has not been subject of research until now. The authors suggest that in future research projects should focus also on standardization of the used techniques, determination of thresholds to discriminate between healthy or diseases or fertile versus infertile and on the predictive value of advanced ultrasound findings.

\section{CONFLICT OF INTEREST}

None of the authors have any conflict of interest to declare.

\section{AUTHOR CONTRIBUTIONS}

Both authors contributed equally to the literature research and to the writing of this paper.

\section{DATA AVAILABILITY STATEMENT}

The data that support the findings of this study are openly available.

\section{ORCID}

George Mantziaras (iD https://orcid.org/0000-0001-9354-1815

Gaia Cecilia Luvoni iD https://orcid.org/0000-0002-9598-9098

\section{REFERENCES}

Alonge, S., Mauri, M., Faustini, M., \& Luvoni, G. C. (2016). Feto-maternal heart rate ratio in pregnant bitches: Effect of gestational age and maternal size. Reproduction in Domestic Animals, 51(5), 688-692. https:// doi.org/10.1111/rda.12731

Alonge, S., Melandri, M., Fanciullo, L., Lacalandra, G. M., \& Aiudi, G. (2018a). Increase in prostatic vascular flow after ejaculation. Reproduction in Domestic Animals, 53(1), 110-115. https://doi. org/10.1111/rda.13078

Alonge, S., Melandri, M., Fanciullo, L., Lacalandra, G. M., \& Aiudi, G. (2018c). Prostate vascular flow: The effect of the ejaculation on the power Doppler ultrasonographic examination. Reproduction in Domestic Animals, 53(1), 110-115. https://doi.org/10.1111/ rda.13078

Alonge, S., Melandri, M., Leoci, R., Lacalandra, G. M., \& Aiudi, G. (2018). Ejaculation effect on blood testosterone and prostatic pulsedwave Doppler ultrasound in dogs. Reproduction in Domestic Animals, 53(Suppl 2), 70-73. https://doi.org/10.1111/rda.13277

Alvarez-Clau, A., \& Liste, F. (2005). Ultrasonographic characterization of the uterine artery in the nonestrus bitch. Ultrasound in Medicine and Biology, 31(12), 1583-1587. https://doi.org/10.1016/j.ultrasmedb io.2005.08.003

Angrimani, D. S. R., Silvestrini, G. R., Brito, M. M., Abreu, R. A., Almeida, L. L., \& Vannucchi, C. I. (2018). Effects of benign prostatic hyperplasia and finasteride therapy on prostatic blood flow in dogs. Theriogenology, 114, 103-108. https://doi.org/10.1016/j.theriogeno logy.2018.03.031

Appis, A. W., Tracy, M. J., \& Feinstein, S. B. (2015). Update on the safety and efficacy of commercial ultrasound contrast agents in cardiac applications. Echo Research and Practice, 2(2), R55-R62. https://doi. org/10.1530/ERP-15-0018
Bamber, J., Cosgrove, D., Dietrich, C. F., Fromageau, J., Bojunga, J., Calliada, F., ... Piscaglia, F. (2013). EFSUMB guidelines and recommendations on the clinical use of ultrasound elastography. Part 1: Basic principles and technology. Ultraschall in der Medizin, 34(2), 169184. https://doi.org/10.1055/s-0033-1335205

Barbosa, C. C., de Souza, M. B., de Freitas, L. A., da Silva, T. F., Domingues, S. F., \& da Silva, L. D. (2013). Assessment of uterine involution in bitches using B-mode and Doppler ultrasonography. Animal Reproduction Science, 139, 121-126. https://doi.org/10.1016/j.anire prosci.2013.02.027

Batista, P. R., Gobello, C., Corrada, Y., Pons, E., Arias, D. O., \& Blanco, P. G. (2013). Doppler ultrasonographic assessment of uterine arteries during normal canine puerperium. Animal Reproduction Science, 141, 172-176. https://doi.org/10.1016/j.anireprosci.2013.07.013

Batista, P. R., Gobello, C., Rube, A., Barrena, J. P., Re, N. E., \& Blanco, P. G. (2018). Reference range of gestational uterine artery resistance index in small canine breeds. Theriogenology, 1(114), 81-84. https:// doi.org/10.1016/j.theriogenology

Batista, P. R., Gobello, C., Rube, A., Corrada, Y. A., Tórtora, M., \& Blanco, P. G. (2016). Uterine blood flow evaluation in bitches suffering from cystic endometrial hyperplasia (CEH) and $\mathrm{CEH}$-pyometra complex. Theriogenology, 85(7), 1258-1261. https://doi.org/10.1016/j.theri ogenology.2015.12.008

Bergeron, L. H., Nykamp, S. G., Brisson, B. A., Madan, P., \& Gartley, C. J. (2013). An evaluation of B-mode and color Doppler ultrasonography for detecting periovulatory events in the bitch. Theriogenology, 79(2), 274-283. https://doi.org/10.1016/j.theri ogenology.2012.08.016

Bigliardi, E., Denti, L., De Cesaris, V., Bertocchi, M., Di lanni, F., Parmigiani, E., ... Cantoni, A. M. (2019). Colour Doppler ultrasound imaging of blood flows variations in neoplastic and non-neoplastic testicular lesions in dogs. Reproduction in Domestic Animals, 54(1), 63-71. https:// doi.org/10.1111/rda.13310

Bigliardi, E., \& Ferrari, L. (2011). Contrast-enhanced ultrasound of the normal canine prostate gland. Veterinary Radiology and Ultrasound, 52(1), 107-110.

Blanco, P. G., Arias, D. O., \& Gobello, C. (2008). Doppler ultrasound in canine pregnancy. Journal of Ultrasound in Medicine, 27(12), 1745-1750. https://doi.org/10.7863/jum.2008.27.12.1745

Blanco, P. G., Arias, D., Rube, A., Barrena, J. P., Corrada, Y., \& Gobello, C. (2009). An experimental model to study resistance index and systolic/diastolic ratio of uterine arteries in adverse canine pregnancy outcome. Reproduction in Domestic Animals, 44(Suppl 2), 164-166. https://doi.org/10.1111/j.1439-0531.2009.01369.x

Blanco, P. G., Batista, P. R., Gómez, F. E., Arias, D. O., \& Gobello, C. (2012). Echocardiographic and Doppler assessment of maternal cardiovascular function in normal and abnormal canine pregnancies. Theriogenology, 78(6), 1235-1242. https://doi.org/10.1016/j.theri ogenology.2012.05.019

Blanco, P. G., Rodríguez, R., Batista, P. R., Barrena, J. P., Arias, D. O., \& Gobello, C. (2015). Bidimensional and Doppler ultrasonographic evaluation of postpartum uterine involution in the queen. Theriogenology, 84(1), 82-85. https://doi.org/10.1016/j.theriogenology.2015.02.013

Blanco, P. G., Rodríguez, R., Olguín, S., Rube, A., Tórtora, M., \& Gobello, C. (2014). Doppler ultrasonographic assessment of maternal and fetal arteries during normal feline gestation. Animal Reproduction Science, 146(1-2), 63-69. https://doi.org/10.1016/j.anireprosci.2014.02.003

Blanco, P. G., Rodríguez, R., Rube, A., Arias, D. O., Tórtora, M., Díaz, J. D., \& Gobello, C. (2011). Doppler ultrasonographic assessment of maternal and fetal blood flow in abnormal canine pregnancy. Animal Reproduction Science, 126(1-2), 130-135. https://doi.org/10.1016/j. anireprosci.2011.04.016

Blanco, P. G., Rube, A., López Merlo, M., Batista, P. R., Arioni, S., López Knudsen, I., ... Gobello, C. (2018). Uterine two-dimensional and Doppler ultrasonographic evaluation of feline pyometra. 
Reproduction in Domestic Animals, 53(Suppl 3), 70-73. https://doi. org/10.1111/rda.13324

Blanco, P. G., Tórtora, M., Rodríguez, R., Arias, D. O., \& Gobello, C. (2011). Ultrasonographic assessment of maternal cardiac function and peripheral circulation during normal gestation in dogs. Veterinary Journal, 190(1), 154-159. https://doi.org/10.1016/j. tvjl.2010.08.013

Blanco, P. G., Vercellini, R., Rube, A., Rodríguez, R., Arias, D. O., \& Gobello, C. (2016). Evaluation of feline uterine and umbilical arteries blood flow in a pharmacologically induced abnormal gestation model. Theriogenology, 86(9), 2323-2327. https://doi.org/10.1016/j. theriogenology.2016.07.028

Buttyan, R., Ghafar, M. A., \& Shabsigh, A. (2000). The effects of androgen deprivation on the prostate gland: Cell death mediated by vascular regression. Current Opinions in Urology, 10, 415-420. https://doi. org/10.1097/00042307-200009000-00009

Calliada, F., Campani, R., Bottinelli, O., Bozzini, A., \& Sommaruga, M. G. (1998). Ultrasound contrast agents: Basic principles. European Journal of Radiology, 27(Suppl 2), S157-S160. https://doi.org/10.1016/ S0720-048X(98)00057-6

Carrillo, J. D., Soler, M., Lucas, X., \& Agut, A. (2012). Colour and pulsed Doppler ultrasonographic study of the canine testis. Reproduction in Domestic Animals, 47(4), 655-659. https://doi. org/10.1111/j.1439-0531.2011.01937.x

Cesarani, F., Isolato, G., Capello, S., \& Bianchi, S. D. (1999). Tridimensional ultrasonography. First clinical experience with dedicated devices and review of the literature. La Radiologia Medica, 4, 256-264.

Cosgrove, D., \& Harvey, C. (2009). Clinical uses of microbubbles in diagnosis and treatment. Medical \& Biological Engineering \& Computing, 47, 813-826. https://doi.org/10.1007/s11517-009-0434-3

de Brito, M., Feliciano, M., Coutinho, L. N., Uscategui, R. R., Simões, A., Maronezi, M. C., ... Russiano, W. R. (2015). Doppler and contrast-enhanced ultrasonography of testicles in adult domestic felines. Reproduction in Domestic Animals, 50(5), 730-734. https://doi. org/10.1111/rda.12557

de Freitas, L. A., Pinto, J. N., Silva, H. V., \& da Silva, L. D. (2015). Twodimensional and Doppler sonographic prostatic appearance of sexually intact French Bulldogs. Theriogenology, 83(7), 1140-1146. https ://doi.org/10.1016/j.theriogenology.2014.12.016

de Souza, M. B., Barbosa, C. C., England, G. C., Mota Filho, A. C., Sousa, C. V., de Carvalho, G. G., ... Silva, L. D. (2015). Regional differences of testicular artery blood flow in post pubertal and pre-pubertal dogs. BMC Veterinary Research, 4(11), 47. https://doi.org/10.1186/ s12917-015-0363-3

de Souza, M. B., da Cunha Barbosa, C., Pereira, B. S., Monteiro, C. L., Pinto, J. N., Linhares, J. C., \& da Silva, L. D. (2014). Doppler velocimetric parameters of the testicular artery in healthy dogs. Research in Veterinary Science, 96(3), 533-536. https://doi.org/10.1016/j. rvsc.2014.03.008

de Souza, M. B., England, G. C., Mota Filho, A. C., Ackermann, C. L., Sousa, C. V., de Carvalho, G. G., ... da Silva, L. D. (2015). Semen quality, testicular B-mode and Doppler ultrasound, and serum testosterone concentrations in dogs with established infertility. Theriogenology, 84(5), 805-810. https://doi.org/10.1016/j.theriogenology.2015.05.015

Di Salvo, P., Bocci, F., Zelli, R., \& Polisca, A. (2006). Doppler evaluation of maternal and fetal vessels during normal gestation in the bitch. Research in Veterinary Science, 81(3), 382-388. https://doi. org/10.1016/j.rvsc.2006.03.004

Domosławska, A., Zduńczyk, S., Jurczak, A., \& Janowski, T. (2018). Elastography as a diagnostic tool in the prostate tumour detection in Labrador retriever. Andrologia, 50(10), e13139. https://doi. org/10.1111/and.13139

Drews, B., Hermes, R., Göritz, F., Gray, C., Kurz, J., Lueders, I., \& Hildebrandt, T. B. (2008). Early embryo development in the elephant assessed by serial ultrasound examinations. Theriogenology, 69, 1120-1128. https://doi.org/10.1016/j.theriogenology.2008.01.026

England, G., Bright, L., Pritchard, B., Bowen, I. M., de Souza, M. B., Silva, L., \& Moxon, R. (2017). Canine reproductive ultrasound examination for predicting future sperm quality. Reproduction in Domestic Animals, 52(Suppl 2), 202-207. https://doi.org/10.1111/rda.12825

England, G. C., Moxon, R., \& Freeman, S. L. (2012). Delayed uterine fluid clearance and reduced uterine perfusion in bitches with endometrial hyperplasia and clinical management with postmating antibiotic. Theriogenology, 78(7), 1611-1617. https://doi.org/10.1016/j.theri ogenology.2012.07.009

Evans, D. H., \& McDicken, W. N. (2000). Doppler ultrasound: Physics, instrumentation and clinical applications. Chichester, UK: Wiley.

Feliciano, M. A., Maronezi, M. C., Pavan, L., Castanheira, T. L., Simões, A. P., Carvalho, C. F., ... Vicente, W. R. (2014). ARFI elastography as a complementary diagnostic method for mammary neoplasia in female dogs - preliminary results. Journal of Small Animal Practice, 55(10), 504-508. https://doi.org/10.1111/jsap.12256

Feliciano, M. A., Maronezi, M. C., Simões, A. P., Uscategui, R. R., Maciel, G. S., Carvalho, C. F., ... Vicente, W. R. (2015). Acoustic radiation force impulse elastography of prostate and testes of healthy dogs: Preliminary results. Journal of Small Animal Practice, 56(5), 320-324. https://doi.org/10.1111/jsap.12323

Feliciano, M. A., Nepomuceno, A. C., Crivalero, R. M., Oliveira, M. E., Coutinho, L. N., \& Vicente, W. R. (2013). Foetal echoencephalography and Doppler ultrasonography of the middle cerebral artery in canine foetuses. Journal of Small Animal Practice, 54(3), 149-152. https ://doi.org/10.1111/jsap.12038

Feliciano, M. A. R., Ramirez, R. A. U., Maronezi, M. C., Maciel, G. S., Avante, M. L., Senhorello, I. L. S., ... Vicente, W. R. R. (2018). Accuracy of four ultrasonography techniques in predicting histopathological classification of canine mammary carcinomas. Veterinary Radiology and Ultrasound, 59(4), 444-452. https://doi.org/10.1111/vru.12606

Feliciano, M. A. R., Uscategui, R., Maronezi, M. C., Simões, A. P. R., Silva, P., Gasser, B., ... Vicente, W. R. R. (2017). Ultrasonography methods for predicting malignancy in canine mammary tumors. PLoS ONE, 12(5), e0178143. https://doi.org/10.1371/journal.pone.0178143

Feliciano, M. A., Vicente, W. R., \& Silva, M. A. (2012). Conventional and Doppler ultrasound for the differentiation of benign and malignant canine mammary tumours. Journal of Small Animal Practice, 53(6), 332-337. https://doi.org/10.1111/j.1748-5827.2012.01227.x

Franck-Lissbrant, I., Haggstrom, S., Damber, J. E., \& Bergh, A. (1998). Testosterone stimulates angiogenesis and vascular regrowth in the ventral prostate in castrated adult rats. Endocinology, 139, 451-456. https://doi.org/10.1210/endo.139.2.5683

Freeman, S. L., Russo, M., \& England, G. C. (2013). Uterine artery blood flow characteristics assessed during oestrus and the early luteal phase of pregnant and non-pregnant bitches. Veterinary Journal, 197(2), 205-210. https://doi.org/10.1016/j.tvjl.2013.02.015

Freitas, L. A., Mota, G. L., Silva, H. V., Carvalho, C. F., \& Silva, L. D. (2016). Can maternal-fetal hemodynamics influence prenatal development in dogs? Animal Reproduction Science, 172, 83-93. https://doi. org/10.1016/j.anireprosci.2016.07.005

Freitas, L. A., Mota, G. L., Silva, H. V. R., \& Silva, L. D. M. (2017). Twodimensional sonographic and Doppler changes in the uteri of bitches according to breed, estrus cycle phase, parity, and fertility. Theriogenology, 95, 171-177. https://doi.org/10.1016/j.theriogeno logy.2017.03.012

Giannico, A. T., Garcia, D. A., Gil, E. M., Sousa, M. G., \& Froes, T. R. (2016). Assessment of umbilical artery flow and fetal heart rate to predict delivery time in bitches. Theriogenology, 86(7), 1654-1661. https:// doi.org/10.1016/j.theriogenology.2016.03.042

Giannico, A. T., Gil, E. M., Garcia, D. A., \& Froes, T. R. (2015). The use of Doppler evaluation of the canine umbilical artery in prediction of 
delivery time and fetal distress. Animal Reproduction Science, 154, 105-112. https://doi.org/10.1016/j.anireprosci.2014.12.018

Gil, E. M., Garcia, D. A., Giannico, A. T., \& Froes, T. R. (2014). Canine fetal heart rate: Do accelerations or decelerations predict the parturition day in bitches? Theriogenology, 82, 933-941. https://doi. org/10.1016/j.theriogenology.2014.04.025

Glińska-Suchocka, K., Jankowski, M., Kubiak, K., Spuzak, J., Dzimira, S., \& Nicpon, J. (2013). Application of shear wave elastography in the diagnosis of mammary gland neoplasm in dogs. Polish Journal of Veterinary Sciences, 16(3), 477-482. https://doi.org/10.2478/ pjvs-2013-0066

Gumbsch, P., Gabler, C., \& Holzmann, A. (2002). Colour-coded duplex sonography of the testes of dogs. Veterinary Record, 151(5), 140-144. https://doi.org/10.1136/vr.151.5.140

Günzel-Apel, A. R., Möhrke, C., \& Poulsen Nautrup, C. (2001). Colourcoded and pulsed Doppler sonography of the canine testis, epididymis and prostate gland: Physiological and pathological findings. Reproduction in Domestic Animals, 36(5), 236-240. https://doi. org/10.1046/j.1439-0531.2001.00288.x

Hagen, E. K., Forsberg, F., Liu, J. B., Gomella, L. G., Aksnes, A. K., Merton, D. A., ... Goldberg, B. B. (2001). Contrast-enhanced power Doppler imaging of normal and decreased blood flow in canine prostates. Ultrasound in Medicine and Biology, 27(7), 909-913. https://doi. org/10.1016/s0301-5629(01)00394-5

Hildebrandt, T. B., Drews, B., Kurz, J., Hermes, R., Yang, S., \& Göritz, F. (2009). Pregnancy monitoring in dogs and cats using 3D and 4D ultrasonography. Reproduction in Domestic Animals, 44(Suppl 2), 125128. https://doi.org/10.1111/j.1439-0531.2009.01429.x

Hildebrandt, T. B., Hermes, R., Painer, J., Jewgenow, K., Rasmussen, K., \& Göritz, F. (2012). Pregnancy characterization in African lioness by $2 D$ and $3 D$ ultrasound (p. 107). Proccedings 17 th EVSSAR-ISCFR Congress, Whistler, Canada July 26-29.

Jeon, S., Lee, G., Lee, S.-K., Kim, H., Yu, D., \& Choi, J. (2015). Ultrasonographic elastography of the liver, spleen, kidneys, and prostate in clinically normal beagle dogs. Veterinary Radiology and Ultrasound, 56, 425-431. https://doi.org/10.1111/vru.12238

Jurczak, A., \& Janowski, T. (2018). Arterial ovarian blood flow in the periovulatory period of $\mathrm{GnRH}$-induced and spontaneous estrous cycles of bitches. Theriogenology, 1(119), 131-136. https://doi.org/10.1016/j. theriogenology.2018.06.014

Kallel, F., Price, R. E., Konofagou, E., \& Ophir, J. (1999). Elastographic imaging of the normal canine prostate in vitro. Ultrasonic Imaging, 21(3), 201-215. https://doi.org/10.1177/016173469902100304

Köster, K., Poulsen, N. C., \& Günzel-Apel, A. R. (2001). A Doppler ultrasonographic study of cyclic changes of ovarian perfusion in the Beagle bitch. Reproduction, 122(3), 453-461. https://doi.org/10.1530/ rep.0.1220453

Kotoyori, Y., Yokoo, N., Ito, K., Murase, H., Sato, F., Korosue, K., \& Nambo, Y. (2012). Three-dimensional ultrasound imaging of the equine fetus. Theriogenology, 77(7), 1480-1486. https://doi.org/10.1016/j.theri ogenology.2011.10.020

Kumar, K., Chandolia, R. K., Kumar, S., Pal, M., \& Sandeep, K. (2015). Two-dimensional and three-dimensional ultrasonography for pregnancy diagnosis and antenatal fetal development in Beetal goats. Veterinary World, 8(7), 835-840. https://doi.org/10.14202/vetwo rld.2015.835-840

Lucio, C. F., Silva, L. C. G., Rodrigues, J. A., Veiga, G. A. L., \& Vannucchi, C. I. (2009). Peripartum haemodynamic status of bitches with normal birth or dystocia. Reproduction in Domestic Animals, 44, 133-136. https://doi.org/10.1111/j.1439-0531.2009.01427.x

Mantziaras, G., \& Luvoni, G. C. (2016). Ultrasound elastography of the normal canine prostate and testicles (p. 65). Proceedings 19th EVSSARISCFR Congress, Paris, France, June 22-25.

Miranda, S. A., \& Domingues, S. F. (2010). Conceptus ecobiometry and triplex Doppler ultrasonography of uterine and umbilical arteries for assessment of fetal viability in dogs. Theriogenology, 74(4), 608-617. https://doi.org/10.1016/j.theriogenology.2010.03.008

Nautrup, C. P. (1998). Doppler ultrasonography of canine maternal and fetal arteries during normal gestation. Journal of Reproduction \& Infertility, 112(2), 301-314. https://doi.org/10.1530/jrf.0.1120301

Newell, S. M., Neuwirth, L., Ginn, P. E., Roberts, G. D., Prime, L. S., \& Harrison, J. M. (1998). Doppler ultrasound of the prostate in normal dogs and in dogs with chronic lymphocytic-lymphoplasmocytic prostatitis. Veterinary Radiology and Ultrasound, 39(4), 332-336.

Nogueira, I. B., Almeida, L. L., Angrimani, D., Brito, M. M., Abreu, R. A., \& Vannucchi, C. I. (2017). Uterine haemodynamic, vascularization and blood pressure changes along the oestrous cycle in bitches. Reproduction in Domestic Animals, 52(Suppl 2), 52-57. https://doi. org/10.1111/rda.12859

Ophir, J., Céspedes, I., Ponnekanti, H., Yazdi, Y., \& Li, X. (1991). Elastography: A quantitative method for imaging the elasticity of biological tissues. Ultrasonic Imaging, 13(2), 111-134. https://doi. org/10.1177/016173469101300201

Orlandi, R., Vallesi, E., Boiti, C., Polisca, A., Troisi, A., Righi, C., \& Bargellini, P. (2019). Contrast-enhanced ultrasonography of maternal and fetal blood flows in pregnant bitches. Theriogenology, 125, 129-134. https ://doi.org/10.1016/j.theriogenology.2018.10.027

Pereira, B. S., Pinto, J. N., Freire, L. M., Campello, C. C., Domingues, S. F., $\&$ da Silva, L. D. (2012). Study of the development of uteroplacental and fetal feline circulation by triplex Doppler. Theriogenology, 77(5), 989-997. https://doi.org/10.1016/j.theriogenology.2011.10.005

Peterson, M. E., \& Kutzler, M. A. (2011). Small animal pediatrics: The first 12 months of life. St. Louis, MO: Elsevier Saunders.

Polisca, A., Orlandi, R., Troisi, A., Brecchia, G., Zerani, M., Boiti, C., \& Zelli, R. (2013). Clinical efficacy of the GnRH agonist (deslorelin) in dogs affected by benign prostatic hyperplasia and evaluation of prostatic blood flow by Doppler ultrasound. Reproduction in Domestic Animals, 48(4), 673-680. https://doi.org/10.1111/rda.12143

Polisca, A., Scotti, L., Orlandi, R., Brecchia, G., \& Boiti, C. (2009). Doppler evaluation of maternal and fetal vessels during normal gestation in rabbits. Theriogenology, 73(3), 358-366. https://doi.org/10.1016/j. theriogenology.2009.09.019

Polisca, A., Scotti, L., Orlandi, R., Brecchia, G., Maranesi, M., Zerani, M., \& Boiti, C. (2010). Aglepristone (RU534) administration to non-pregnant bitches in the mid-luteal phase induces early luteal regression. Theriogenology, 74(4), 672-681. https://doi.org/10.1016/j.theriogeno logy.2010.03.021

Polisca, A., Zelli, R., Troisi, A., Orlandi, R., Brecchia, G., \& Boiti, C. (2013). Power and pulsed Doppler evaluation of ovarian hemodynamic changes during diestrus in pregnant and nonpregnant bitches. Theriogenology, 79(2), 219-224. https://doi.org/10.1016/j.theriogeno logy.2012.08.005

Pozniak, M. A., \& Allan, P. L. (2014). Clinical Doppler ultrasound (3rd ed.). Edinburgh, UK: Elsevier Limited.

Rodrigues Simões, A. P., Rossi Feliciano, M. A., Maronezi, M. C., Uscategui, R. A. R., Bartlewski, P. M., de Almeida, V. T., ... Russiano Vicente, W. R. (2018). Elastographic and echotextural characteristics of foetal lungs and liver during the final 5 days of intrauterine development in dogs. Animal Reproduction Science, 197, 170-176. https:// doi.org/10.1016/j.anireprosci.2018.08.025

Russo, M., Vignoli, M., Catone, G., Rossi, F., Attanasi, G., \& England, G. C. (2009). Prostatic perfusion in the dog using contrast-enhanced Doppler ultrasound. Reproduction in Domestic Animals, 44(Suppl 2), 334-335. https://doi.org/10.1111/j.1439-0531.2009.01442.x

Russo, M., Vignoli, M., \& England, G. (2012). B-mode and contrast-enhanced ultrasonographic findings in canine prostatic disorders. Reproduction in Domestic Animals, 47(Suppl 6), 238-242. https://doi. org/10.1111/rda.12059

Scully, S., Evans, A. C., Duffy, P., \& Crowe, M. A. (2014). Characterization of follicle and $\mathrm{CL}$ development in beef heifers using high resolution 
three-dimensional ultrasonography. Theriogenology, 81(3), 407-418. https://doi.org/10.1016/j.theriogenology.2013.10.012

Soler, M., Dominguez, E., Lucas, X., Novellas, R., Gomes-Coelho, K. V., Espada, Y., \& Agut, A. (2016). Comparison between ultrasonographic findings of benign and malignant canine mammary gland tumours using B-mode, colour Doppler, power Doppler and spectral Doppler. Research in Veterinary Science, 107, 141-146. https://doi. org/10.1016/j.rvsc.2016.05.015

Trasch, K., Wehrend, A., \& Bostedt, H. (2007). Ultrasonographic description of canine mastitis. Veterinary Radiology and Ultrasound, 48(6), 580-584. https://doi.org/10.1111/j.1740-8261.2007.00301.x

Trautwein, L. G. C., Souza, A. K., \& Martins, M. I. M. (2019). Can testicular artery Doppler velocimetry values change according to the measured region in dogs? Reproduction in Domestic Animals, 54(4), 687-695. https://doi.org/10.1111/rda.13410

Troisi, A., Orlandi, R., Bargellini, P., Menchetti, L., Borges, P., Zelli, R., \& Polisca, A. (2015). Contrast-enhanced ultrasonographic characteristics of the diseased canine prostate gland. Theriogenology, 84(8), 1423-1430. https://doi.org/10.1016/j.theriogenology.2015.07.029

Vanderperren, K., Saunders, J. H., Van der Vekens, E., Wydooghe, E., de Rooster, H., Duchateau, L., \& Stock, E. (2018). B-mode and contrast-enhanced ultrasonography of the mammary gland during the estrous cycle of dogs. Animal Reproduction Science, 199, 15-23. https ://doi.org/10.1016/j.anireprosci.2018.08.036

Veiga, G. A., Miziara, R. H., Angrimani, D. S., Papa, P. C., Cogliati, B., \& Vannucchi, C. I. (2017). Cystic endometrial hyperplasia-pyometra syndrome in bitches: Identification of hemodynamic, inflammatory, and cell proliferation changes. Biology of Reproduction, 96(1), 58-69. https://doi.org/10.1095/biolreprod.116.140780

Vercellini, R., Gobello, C., D'Francisco, F., Olguín, S., Arizmendi, A., Rodríguez, R., ... Blanco, P. G. (2018). Ultrasonographic evaluation of ovarian morphology and blood flow in prepubertal and pubertal cats. Reproduction in Domestic Animals, 53(Suppl 3), 74-78. https:// doi.org/10.1111/rda.13355

Vestegen, J. P., Silvia, L. D. M., Onclin, K., \& Donnay, I. (1993). Echocardiographic study of heart rate in dog and cat fetuses in utero. Journal of Reproduction and Fertility. Supplement, 47, 175-180.
Vignoli, M., Russo, M., Catone, G., Rossi, F., Attanasi, G., Terragni, R., ... England, G. (2011). Assessment of vascular perfusion kinetics using contrast-enhanced ultrasound for the diagnosis of prostatic disease in dogs. Reproduction in Domestic Animals, 46(2), 209-213. https:// doi.org/10.1111/j.1439-0531.2010.01629.x

Volta, A., Manfredi, S., Vignoli, M., Russo, M., England, G. C., Rossi, F., ... Gnudi, G. (2014). Use of contrast-enhanced ultrasonography in chronic pathologic canine testes. Reproduction in Domestic Animals, 49(2), 202-209. https://doi.org/10.1111/rda.12250

Yeager, A. E., \& Concannon, P. W. (1990). Association between the preovulatory luteinizing hormone surge and the early ultrasonographic detection of pregnancy and fetal heartbeats in Beagle dogs. Theriogenology, 34, 655-665. https://doi. org/10.1016/0093-691x(90)90021-k

Zelli, R., Orlandi, R., Troisi, A., Cardinali, L., \& Polisca, A. (2013). Power and pulsed Doppler evaluation of prostatic artery blood flow in normal and benign prostatic hyperplasia-affected dogs. Reproduction in Domestic Animals, 48(5), 768-773. https://doi.org/10.1111/ rda.12159

Zelli, R., Troisi, A., Elad Ngonput, A., Cardinali, L., \& Polisca, A. (2013). Evaluation of testicular artery blood flow by Doppler ultrasonography as a predictor of spermatogenesis in the dog. Research in Veterinary Science, 95(2), 632-637. https://doi.org/10.1016/j.rvsc.2013.04.023

Zone, M. A., \& Wanke, M. M. (2001). Diagnosis of canine fetal health by ultrasonography. Journal of Reproduction and Fertility. Supplement, 57(2), 5-219.

How to cite this article: Mantziaras G, Luvoni GC. Advanced ultrasound techniques in small animal reproduction imaging. Reprod Dom Anim. 2020;55(Suppl. 2):17-25. https://doi. org/10.1111/rda.13587 